\title{
МЕТОДИЧНІ ПІДХОДИ ДО ПОЗИЦІОНУВАННЯ ЛІКУВАЛЬНО-КОСМЕТИЧНИХ ЗАСОБІВ
}

\author{
() О. В. Посилкіна, В. Г. Котлярова, О. В. Чечотка
}

\author{
Національний фрармацевтичний університет, Харків \\ vgkotlarova@i.ua
}

\begin{abstract}
Мета роботи. Розробка методичних підходів до позиціонування лікувально-косметичних засобів із врахуванням особливостей різних сегментів споживачів.

Матеріали і методи. Метод контрольного опитування, метод експертного опитування, шкала Р. Лайкерта.

Результати й обговорення. Проведені дослідження показали, що всіх споживачів лікувально-косметичних засобів (ЛКЗ) можна розподілити на дві основні категорії: потенційних та постійних споживачів. Для підвищення есрективності просування ЛКЗ фрармацевтичним компаніям (ФК) необхідно позиціонувати ЛКЗ із врахуванням особливостей їх сприйняття кожним із сегментів споживачів. Для цих сегментів розроблені алгоритми позиціонування ЛКЗ, спрямованих на підкреслення переваг, які отримають споживачі від їх використання.

Висновки. Впровадження запропонованих підходів позиціонування ЛКЗ спрямоване на підвищення інсрормованості різних груп споживачів про особливості різних ЛКЗ та фрормування стійких вподобань споживачів на основі розуміння одержуваних переваг, що буде сприяти підвищенню ефективності просування ЛКЗ.
\end{abstract}

Ключові слова: лікувально-косметичні засоби; позиціонування; сегменти споживачів.

Вступ. Сьогодення характеризується розширенням асортименту фрармацевтичної продукції, яка виходять на ринок. 3 метою ознайомлення потенційних споживачів із новою продукцією та фрормування в їх свідомості позитивного ставлення до неї, фрармацевтичним компаніям (ФК) необхідно її грамотно позиціонувати серед інших товарів-аналогів.

Згідно з Законом України «Про лікарські засоби» до складу лікарських засобів (ЛЗ) відносяться: АФІ (активний фрармацевтичний інгредієнт), продукція «іn bulk»; готові лікарські засоби; гомеопатичні засоби; засоби, які використовуються для виявлення збудників хвороб, а також боротьби із збудниками хвороб або паразитами; лікарські косметичні засоби та лікарські домішки до харчових продуктів» [1].

Питанням позиціонування окремих складових ЛЗ присвячено багато досліджень, зокрема, Б. Громовика, Л. Дмитренка, 3. Мнушко, А. Немченко, Толочка, Н. Чухрай та ін. [2-7]. Визначено принципи і підходи до позиціонування деяких видів фрармацевтичної продукції, а саме: готових Л3, лікарських домішок до харчових продуктів, гомеопатичних засобів, але до питань позиціонування лкз уваги до цього часу не приділяли.

Мета роботи - розробка методичних підходів до позиціонування ЛкЗ з урахуванням особливостей різних сегментів споживачів.

Матеріали і методи. 3 метою дослідження ставлення споживачів до лкз та розробки методичних підходів до позиціонування використано метод контрольного опитування, метод експертного опитування та шкалу Р. Лайкерта.

Результати й обговорення. Проведені дослідження показали, що дерматологічні проблеми мають понад 80 \% населення України, 3 них 36 \% - постійно користуються Лк3; 57 \% - потенційні користувачі, 7\% застосовували лК3 хоча б один раз, але не були задоволені результатом [8]. Тобто всіх споживачів лкЗ можна розподілити на дві основні категорії: потенційних і постійних споживачів. Тому для підвищення ефективності просування ЛКЗ ФК необхідно позиціонувати ЛКЗ із врахуванням особливостей їх сприйняття кожним із сегментів споживачів. Відповідно повинні використовуватися для цих цілей і різні методичні підходи щодо сегментації (рис. 1).

Наведені відмінності вимагають розробки адаптованих методик позиціонування ЛКЗ для цих сегментів досліджуваного ринку засобів вирішення дерматологічних проблем шкіри (РЗВДПШ).

Для позиціонування ЛКЗ для сегмента потенційних споживачів запропоновано наступний алгоритм.

Етап 1. Визначення поточного сприйняття ЛКЗ. Для цього необхідно здійснити наступні операції:

1.1. Опитування відвідувачів аптечних закладів, які мають дерматологічні проблеми шкіри, щодо їх ставлення до ЛкЗ з використанням шкали Р. Лайкерта. 
Фармацевтичний менеджмент, маркетинг та логістика

Pharmaceutical management, marketing and logistics

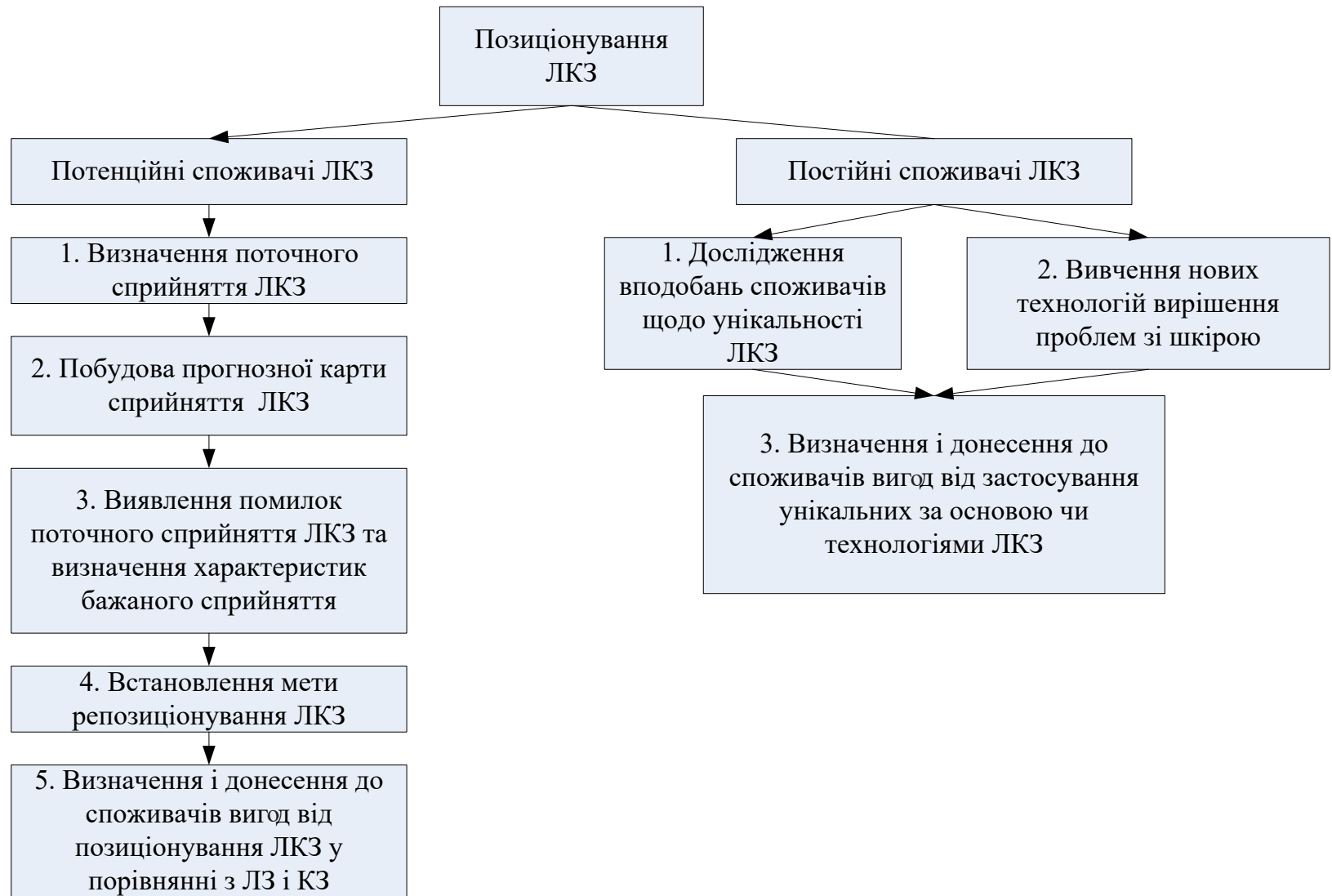

Рис. 1. Схема етапів позиціонування лкз для сегментів потенційних та постійних споживачів.

1.1.1. Розробка відповідної анкети.

1.1.2. Проведення опитування (для забезпечення репрезентативності вибірки необхідно опитати не менше 300 споживачів).

1.1.3. Обробка результатів опитування за шкалою Р. Лайкерта [9].

Для отримання сумарної оцінки ставлення споживача до ЛКЗ розраховується середньоариорметична оцінка відповідей. При рівні загальної середньої оцінки від 3 до 5 балів ставлення споживачів до ЛкЗ оцінюється як позитивне.

1.1.4. Аналіз фрахівцями відповідей на окремі питання анкети. 3 метою виявлення місця ЛКЗ в уявленні потенційних споживачів відносно товарів-замінників, які реалізуються на РЗВДПШ, необхідно проаналізувати та оцінити їх відповіді на окремі питання анкети.

3 метою визначення найбільш доцільних інструментів й прийомів позиціонування ЛКЗ, авторами було проведено опитування 328 відвідувачів аптек м. Харкова, Запоріжжя, Києва та Львова.

Аналіз усереднених результатів дослідження показав наступне: із твердженнями «ЛКЗ застосовуються 3 метою профілактики та лікування дефектів шкіри» та «ЛКЗ за концентрацією АФІ, рівнем впливу та механізмом дії більш безпечні, ніж ЛЗ» - понад 60 \% потенційних споживачів не згідні, а 20 \% склад- но відповісти; із твердженнями: «ЛКЗ є різновидом К3» та «результати застосування ЛКЗ, КЗ класів «профрі» та «люкс» ідентичні» - 73 \% споживачів згідні; 7 \% складно відповісти; із твердженнями: «проблеми шкіри можна вирішити тільки шляхом застосування ЛЗ» та «засоби органічної косметики (ОК) та натуральної косметики (НК) внаслідок натуральності складу гарантують лікувальний ефект» - 89 \% потенційних споживачів повністю згідні та на твердження «ціна ЛКЗ відповідає ефекту від їх застосування»не мають відповіді $33 \%$.

1.2. Побудова поточної карти сприйняття лКз потенційними споживачами.

1.2.1. Визначення основних диференційованих характеристик ЛКЗ за сприйняттям споживачів.

За результатами опитування потенційних споживачів як основні характеристики вибору ЛКЗ рекомендується обрати - мету застосування і ціну.

1.2.2. Нанесення на карту поточного місця знаходження ЛКЗ в уявленні потенційних споживачів. В подальшому результати аналізу ставлення потенційних споживачів до ЛКЗ за шкалою Р. Лайкерта наносяться на осі координат. Також були використані результати опитування 328 відвідувачів аптечних закладів м. Харкова, Запоріжжя, Києва та Львова.

Проведений аналіз сприйняття споживачами означених засобів показав наступне:

ISSN 2312-0967. Фармацевтичний часопис. 2017. № 4 
- основними дисеренційованими характеристиками засобів, що використовуються для догляду за шкірою, досліджувана група споживачів обрала «мету застосування і ціну». Отже, при побудові карти сприйняття на вісь $X$ наносяться дані щодо засобу, на вісь $Y$ - мету застосування;

- для вирішення дерматологічних проблем 7 \% споживачів вважають за краще використовувати Л3, сприймаючи ЛКЗ як КЗ;

- засоби органічної та натуральної косметики 72 \% споживачів сприймають як ЛКЗ;

- косметику класів «люкс» та «профрі» 87 \% споживачів вважають тотожною до ЛКЗ.

Етап 2. Побудова прогнозної карти сприйняття ЛКЗ потенційними споживачами.

2.1. Визначення основних диференційованих характеристик ЛкЗ на думку фрахівців. До складу фрахівців, які брали участь у експертному дослідженні, входили: провізори та лікарі-косметологи. Необхідна кількість експертів для проведення дослідження розраховувалася за методикою [10]. Збіжність висновків була невипадкова, що характеризується рівнем коефріцієнта конкордації - 0,87 та підтверджується критерієм Пірсона $\chi^{2}$, який дорівнює 136,5 . У результаті дослідження було виявлено, що основними диференційованими характеристиками ЛКЗ, на думку фрахівців, слід вважати: вміст АФІ та есрективність впливу засобу на організм.

2.2. Нанесення на карту сприйняття потенційними споживачами прогнозованого місця знаходження засобів для лікування та профрілактики дерматологічних проблем шкіри, за оцінкою експертів. Результати дослідження наносяться вісь координат: на вісь $X-$ вміст АФІ, на вісь $Y$ - рівень впливу засобу на організм.

Етап 3. Виявлення помилок поточного сприйняття ЛКЗ. Виявлення помилок сприйняття ЛКЗ здійснюється за допомогою методу порівняння результатів дослідження поточної та прогнозної карт сприйняття.

Порівняння показало, що поточне сприйняття ЛКЗ потенційними споживачами значною мірою $є$ помилковим.

1. Невірним $€$ ототожнення лЗ та ЛКЗ, які відрізняються за низкою характеристик: предметом та метою впливу, концентрацією АФІ, характером дії, рівнем впливу та іншими характеристиками, тому їх механічне ототожнення $€$ помилковим.

2. Ототожнення ЛКЗ і ОК також $є$ невірним. Органічність КЗ характеризується принципами вирощування та виробництва, але не гарантує лікувальної дії.

3. Косметику «люкс» споживачі сприймають близькою за характеристиками до ЛКЗ внаслідок її високої ціни. Але згідно з характеристиками остання виконує лише гігієнічні, профрілактичні та естетичні фрункції. Висока ціна пояснюється більш безпечним складом цієї продукції та високим рівнем використовуваних технологій. Косметику «профрі» споживачі сприймають як лікувальну через те, що нею користуються косметологи в салонах краси, та вона забезпечує швидкий естетичний ефрект [8].

Етап 4. Встановлення мети репозиціонування ЛКЗ. На основі виявлення і аналізу помилок у сприйнятті потенційними споживачами ЛКЗ та визначення характеристик бажаного сприйняття фрормується мета репозиціонування ЛКЗ як засобу, що, крім косметичного (естетичного), має і лікувальний ефрект.

Eтап 5. Визначення та донесення до споживачів переваг від застосування ЛКЗ та позиціонування товарної категорії ЛКЗ серед інших засобів. Для позиціонування пропонується використовувати дослідження науковців щодо технології його проведення [11, 12]. Характеристики елементів позиціонування для сегмента потенційних споживачів ЛКЗ наведено в таблиці 1.

Постійні споживачі лікувальної косметики у вирішенні дерматологічних проблем використовують ЛКЗ та вже оцінили їх як засоби з комплексним ефектом (лікувальним та косметичним). Але дослідження профрілю постійних споживачів ЛКЗ показало, що для них значною мірою важлива унікальність торгової марки [13]. Відповідно, стратегію позиціонування необхідно будувати з урахуванням цього фрактора.

Запропонований алгоритм позиціонування лКЗ для постійних споживачів включає наступні етапи.

1. Дослідження вподобань споживачів щодо складу та новизни ЛКЗ. Дослідження доцільно проводити за допомогою методу контрольного опитування.

Таблиця 1. Характеристики елементів позиціонування Лк3 для сегмента потенційних споживачів

\begin{tabular}{|c|c|}
\hline Елементи позиціонування & Характеристика елемента \\
\hline $\begin{array}{l}\text { Сутність товарної категорії } \\
\text { ЛкЗ }\end{array}$ & ЛКЗ - лікувальний засіб, який також має косметичний ефект \\
\hline Стратегія позиціонування & $\begin{array}{l}\text { Позиціонування на базі відмінних переваг товару, важливих для споживачів } \\
\text { певного сегмента ринку }\end{array}$ \\
\hline Спосіб позиціонування & «Проти товарної категорії» \\
\hline $\begin{array}{l}\text { Переваги товарної категорії } \\
\text { Лк3, які пропонує виробник }\end{array}$ & $\begin{array}{l}\text { - наявність у ЛКЗ АФІ, що надає їм лікувальний есект } \\
\text { - місцеве застосування }\end{array}$ \\
\hline $\begin{array}{l}\text { Переваги товарної категорії } \\
\text { ЛКЗ, які отримує споживач }\end{array}$ & $\begin{array}{l}\text { - зручність вирішення дерматологічних проблем «на дому» } \\
\text { - ефективність вирішення проблем зі шкірою } \\
\text { - безпечність вирішення проблем зі шкірою }\end{array}$ \\
\hline
\end{tabular}

ISSN 2312-0967. Pharmaceutical review. 2017. № 4 
Фармацевтичний менеджмент, маркетинг та логістика Pharmaceutical management, marketing and logistics

1.1. Розробка питань анкети.

1.2. Проведення опитування. Для забезпечення репрезентативності вибірки необхідно опитати не менше 300 споживачів.

1.3. Обробка результатів опитування. В результаті обробки результатів проведеного опитування виявлено:

- і при профрілактиці, і при лікуванні дерматологічних проблем (незалежно від захворювання) для 74,6 \% опитаних має значення склад та для 72 \% ступінь новизни ЛКЗ;

- із числа опитаних респондентів, для яких має значення склад, - 54,6 \% надають перевагу Лк3 на основі термальної води, 26,4 \% - фрітокомпонентів, 9,7 \% - на основі інноваційних технологій, 5,7 \% - органічним ЛКЗ та $4 \%$ - мінеральним ЛК3;

- 71 \% опитаних спостерігає за розвитком технологій виробництва ЛКЗ та охоче використовують «новинки».
Таким чином, серед постійних споживачів виокремлюються цільові групи (сегменти) за вподобанням щодо унікальності ЛКЗ: постійні споживачі, які застосовують ЛКЗ на основі термальної води, фрітокомпонентів, інноваційних технологій, мінеральні та органічні ЛКЗ.

2. Пошук та вивчення нових технологій вирішення проблем зі шкірою, який рекомендується проводити за допомогою контент-аналізу звітів дослідницьких лабораторій відповідних торгових марок.

3. Визначення і донесення до споживачів переваг від застосування унікальних за основою чи технологіями ЛКЗ. Для ефрективного позиціонування ЛКЗ пропонується використовувати адаптовані методики.

Характеристики елементів позиціонування ЛКЗ для сегмента постійних споживачів наведено в таблиці 2.

Таблиця 2. Характеристики елементів позиціонування ЛКЗ для сегмента постійних споживачів

\begin{tabular}{|l|l|}
\hline \multicolumn{1}{|c|}{ Елементи позиціонування } & \multicolumn{1}{|c|}{ Характеристика елемента } \\
\hline Сутність відмінності атрибуту & $\begin{array}{l}\text { Відмінним атрибутом певного ЛКЗ є унікальність ТМ за складом, соормулою чи } \\
\text { інноваційністю технології }\end{array}$ \\
\hline Стратегія позиціонування & $\begin{array}{l}\text { Позиціонування на базі вподобань, важливих для різних цільових груп } \\
\text { споживачів }\end{array}$ \\
\hline Спосіб позиціонування & «Позиціонування за атрибутом» \\
\hline $\begin{array}{l}\text { Переваги від унікальності } \\
\text { бренду, що пропонує виробник }\end{array}$ & ЛКз розробляють на основі базових інновацій власних лабораторій ТМ \\
\hline $\begin{array}{l}\text { Переваги від унікальності } \\
\text { бренду, що отримує споживач }\end{array}$ & Індивідуалізація підходу до вирішення дерматологічних проблем споживача \\
\hline
\end{tabular}

Висновки. Впровадження запропонованих підходів до позиціонування ЛКЗ спрямовані на підвищення обізнаності різних груп споживачів щодо переваг різних
ЛКЗ і фрормування стійких вподобань споживачів на підставі розуміння одержуваних переваг (есректа), що сприятиме підвищенню ефективності просування ЛКЗ.

\section{МЕТОДИЧЕСКИЕ ПОДХОДЫ К ПОЗИЦИОНИРОВАНИЮ ЛЕЧЕБНО-КОСМЕТИЧЕСКИХ СРЕДСТВ}

\section{О. В. Посылкина, В. Г. Котлярова, Е. В. Чечотка}

Национальный фрармацевтический университет, Харьков

vgkotlarova@i.ua

Цель работы. Разработка методических подходов к позиционированию лКс с учетом особенностей различных сегментов потребителей.

Материалы и методы. Метод контрольного опроса, метод экспертного опроса, шкала Р. Лайкерта.

Результаты и обсуждение. Проведенные исследования показали, что всех потребителей ЛКС можно разделить на две основные категории: потенциальных и постоянных потребителей. Для повышения эфффективности продвижения ЛКС ФК необходимо позиционировать ЛКС с учетом особенностей их восприятия каждым из сегментов потребителей. Для этих сегментов разработаны алгоритмы позиционирования ЛКС, направленные на выделение выгод, которые получат потребители от их использования.

Выводы. Внедрение предложенных подходов позиционирования лКС направлено на повышение информированности различных групп потребителей об особенностях различных лКС и фрормирования стойких предпочтений потребителей на основе понимания получаемых выгод (эфффекта), что будет способствовать повышению эффективности продвижения ЛКС.

Ключевые слова: лечебно-косметические средства; позиционирование; сегменты потребителей.

ISSN 2312-0967. Фармацевтичний часопис. 2017. № 4 


\title{
METHODOLOGICAL APPROACHES TO THE MARKETING OF MEDICAL AND COSMETIC PRODUCTS
}

\author{
O. V. Posilkina, V. G. Kotlyarova, O. V. Chechotka \\ National University of Pharmacy, Kharkiv \\ vgkotlarova@i.ua
}

The aim of the work. Development of methodical recommendations on the medical and cosmetic products (MCP) marketing with due regard to the particularities of different segments of consumers.

Materials and Methods. Method of control survey, the method of expert survey and the scale of R. Likert.

Results and Discussion. The conducted research has shown that all MCP consumers may be divided into two main categories: potential consumers and permanent customers. Pharmaceutical companies have to promote the MCP with due regard to the peculiarities of their perception by each of the consumer segments in order to increase the efficiency of the MCP promotion. For these segments, MCP positioning algorithms have been developed, aimed at identifying the benefits that consumers will receive from their use.

Conclusions. Implementation of the proposed approaches to the MCP marketing is aimed at raising the awareness of different groups of consumers regarding the advantages of different MCP and formation of sustainable consumer preferences based on an understanding of the received benefits (effect) that will increase the effectiveness of the MCP promotion.

Key words: medical and cosmetic products; positioning; consumer segments.

\section{Список літератури}

1. Про лікарські засоби : Закон України від 4.04.1996 р. № 123/96-BP. [Електронний ресурс]. - Режим доступу: http://zakon3.rada.gov.ua/laws/show/ 123/96-\%D0\%B2\%D1\%80.

2. Громовик Б. П. Менеджмент і маркетинг у фрармації : підручник / Б. П. Громовик, Г. Д. Гасюк, О. Р. Левицька. К. : Медицина, 2008. - С. 149-185.

3. Дмитренко Л. А. Менеджмент і маркетинг у фрармації : навч. посіб. / Л. А. Дмитренко, Н. П. Завадська, Н. М. Косяченко. - К. : Медицина, 2010. - 144 с.

4. Мнушко 3. М. Менеджмент та маркетинг у фрармації. Ч. І. Менеджмент у фрармації : підручн. / 3. М. Мнушко, Н. М. Діхтярьова. - Х. : НФаУ : Золоті сторінки, 2009. $448 \mathrm{c}$.

5. Немченко А. С. Анкетне опитування споживачів і провізорів оптової та роздрібної мережі щодо державного регулювання обігу парафрармацевтичних засобів для догляду за волоссям /А. С. Немченко, В.І.Міщенко // Запорожский медицинский журнал. - 2013. - № 5. C. 88-91.

6. Толочко В. М. Управління фрармацією / В. М. Толочко. - Х. : Вид-во Національного фрармацевтичного університету, 2004. - 386 c.

\section{References}

1. Zakon Ukrainy vid 04.04.1996 № 123/96-BP. «About medicinal facilities» Available from: http://zakon3.rada.gov.ua/ laws/show/ 123/96-\%D0\%B2\%D1\%80. Ukrainian.

2. Hromovyk BP. Management and marketing in pharmaceutical industry. [Менеджмент і маркетинг у фрармації: підручник] Kyiv: Medicine; 2008. Ukrainian.

3. Dmytrenko LA. Management and marketing in pharmaceutical industry. [Менеджмент і маркетинг у фрармації: навч. посіб] Kyiv: Medicine; 2010. Ukrainian.
7. Фармацевтичний маркетинг : навч. посібн.; зб. вправ / [Б. П. Громовик, Г. Д. Гасюк, Л. А. Мороз, Н. І. Чухрай.]. - Львів : Вид-во «Наутилус», 2000. - 320 с

8. Посилкіна О. В. Аналіз особливостей розвитку ринку лікувальної косметики в Україні / О.В.Посилкіна, В. Г.Котлярова, О.В.Чечотка // Управління й економіка та забезпечення якості в фрармації. - 2016. - № 4 (48). - C. 38-44.

9. Балабанова Л. В. Маркетинг : підручник / Л. В. Балабанова. - Київ : КНЕУ, 2011. - 543 с.

10. Моделі і методи соціально-економічного прогнозування: підручник / В. М. Геєць, Т. С. Клебанова, О. І. Черняк та ін. - Х. : ВД «ІНЖЕК», 2005. - 396 с.

11. Principles of marketing / Philip Kotler, Gary Armstrong. Englewood Cliffs, N.J. ; Singapore : Prentice Hall, c 1996. 12. Walker O. Marketing strategy: Planning and implementation / O. Walker, C. Larreche. - 2ed. - Boston: Irwin: McGraw Hill, 1996. - 392 p.

13. Посилкіна О. В. Дослідження характеристик споживачів лікувальної косметики в Україні / О.В.Посилкіна, В. Г. Котлярова, О. В. Чечотка // Scientific Journal «ScienceRise: Pharmaceutical Science». - № 4(4). - 2016. C. $53-59$.

4. Mnyshko ZN. Management and marketing in pharmaceutical industry. Ch.1. Management in pharmaceutical industry. [Менеджмент та маркетинг у фрармації. Ч. І. Менеджмент у фрармації: підручн.] Kharkov: Gold pages; 2010. Ukrainian.

5. Nemchenko AS, Mychshenko VI. [Questionnaire survey of consumers and pharmacists of wholesale and retail network in relation to government control of turnover of parapharmaceutical facilities for the care of hair]. Zaporizhzhia 
Medical Journal. 2013;5: 88-91 Ukrainian.

6. Tolochko VM. Management by pharmaceutical industry. [Управління фрармацією] Kharkiv: Publishing house: National University of Pharmacy; 2004. Ukrainian.

7. Hromovyk BP, editors. Pharmaceutical marketing [Фармацевтичний маркетинг : навч. посібн.; зб. Вправ] Lviv: Publishing house: Nautilus; 2000. Ukrainian.

8. Posylkina AV, Kotliarova VH, Chechotka OV. [Analysis of peculiarities of growth for the medical cosmetics market in Ukraine]. Management and Economy and Providing of Quality in Pharmaceutical Industry. 2016;4(48): 38-44. Ukrainian.
9. Balabanova LV. Marketing. Kyiv: KNEY; 2011. 543 p.

10. Geyec VM, editors. Models and methods of socioeconomic prognostication. [Моделі і методи соціальноекономічного прогнозування: підручник] Kharkiv: VD INGEK; 2005. Ukrainian.

11. Kotler Ph. Principles of marketing. Englewood Cliffs, N.J.; Singapore: Prentice Hall; 1996.

12. Walker O. Marketing strategy: Planning and implementation. 2ed. Boston: Irwin: McGraw Hill; 1996.

13. Posylkina AV, Kotliarova VH, Chechotka OV. Research on the characteristics of medical cosmetics consumers in Ukraine. Scientific Journal «ScienceRise: Pharmaceutical Science». 2016;4(4): 53-9. Ukrainian.

Отримано 04.10.2017 